Jarosław JAŃCZAK

Uniwersytet im. Adama Mickiewicza, Poznań

\title{
Na granicy Unii Europejskiej - pozycja europejskich terytoriów autonomicznych w dobie globalizacji i integracji. Przypadek Wysp Alandzkich
}

\section{Globalizacja i integracja a regionalizm i autonomia}

G lobalizacja postrzegana jest częstokroć poprzez pryzmat likwidacji barier w rozwoju gospodarki światowej oraz liberalizacji zasad, na jakich ona funkcjonuje. Konkurencja, specjalizacja, wolny handel oraz korporacje międzynarodowe są czynnikami determinującymi funkcjonowanie globalizacji na gruncie ekonomicznym. Procesy globalizacji nie zachodza jednak wyłącznie w sferze gospodarczej. Jest ona widoczna również w wielu innych dziedzinach tj. kultura, polityka, ochrona środowiska, które wzajemnie na siebie wpływają ${ }^{1}$. Oprócz cech o charakterze ekonomicznym globalizacja to także ,[...] przepływ w skali globu [...] wartości niematerialnych oraz zachowań społecznych, norm kulturowych oraz politycznych, a jej rezultatem jest stałe formowanie nowych i na razie nieznanych więzi kulturowych, które różnią się od dotychczasowych, ukształtowanych przez narody i grupy etniczne". Wartości niematerialne pochodzące z innych kultur wpływają na lokalne zwyczaje i stosunki społeczne, obszar wartości oraz przestrzeń tożsamości ${ }^{2}$. W dziedzinie politycznej globalizacja oznacza natomiast utratę pełnej niezależności państwa w kreowaniu polityk wewnętrznych i zewnętrznych ${ }^{3}$.

Globalizacja jawi się jako proces wielowymiarowy przedmiotowo oraz wielopodmiotowy przestrzennie, obejmując zasięgiem zdecydowaną większość państw i społeczeństw. Jej składnikami są tak integracja, jak

1 T. Wallas, Globalizacja. Przyczynek do rozważań nad jej istota i skutkami, w: Europa Środkowo-Wschodnia a globalizacja, pod red. T. Wallasa, Poznań 2000, s. 8.

2 J. Zdanowski, Globalizacja-pytania i niepokoje, w: Kultury pozaeuropejskie $i$ globalizacja. Zderzenia, pod red. J. Zdanowskiego, Warszawa 2000, s. 7-8.

3 M. Golka, Cywilizacja. Europa. Globalizacja, Poznań 1999, s. 147. 
i dezintegracja, unifikacja oraz różnicowanie. Istotną kwestią wydaje się być pytanie o relację pomiędzy globalizacją a regionalizacją ${ }^{4}$.

Regionalizację można postrzegać jako reakcję na globalizację. W wyniku kurczenia się świata oraz jego ujednolicania, społeczności ludzkie zmuszone są do poszukiwania własnej tożsamości poprzez odwoływanie się do tego, co lokalne, na gruncie nie tylko kulturowym, ale również politycznym i ekonomicznym. Z drugiej strony relacje pomiędzy globalizacją a lokalnością mogą postrzegane być jako zależności o charakterze korelacyjnym, a nie przyczynowo-skutkowym. W takim ujęciu zmniejszanie znaczenia tradycyjnie rozumianego państwa narodowego przebiega w dwóch kierunkach: „na zewnątrz” i „do wewnątrz”. Kompetencje przekazywane są strukturom ponadpaństwowym oraz regionalnym. Następuje również aktywizacja obydwu tych obszarów. Jedną z charakterystycznych cech politycznego aspektu globalizacji jest zatem rozdrabnianie polityczne współczesnego świata ${ }^{5}$, czego konsekwencją jest dążenie do autonomizacji oraz powstawania mini-państw, autonomicznych bądź niezależnych regionów oraz innych bytów politycznych.

Formą upodmiotowienia regionalnego jest m.in. autonomizacja. Autonomia polityczna jest wyrazem ,[...] woli ochrony swoistych interesów, zwłaszcza kulturowych tych grup, które z uwagi na swą liczebność, i związaną z tym słabość reprezentacji w parlamencie lub rządzie, nie są w stanie wykorzystać dla realizacji własnych interesów demokratycznej procedury decydowania większością głosów"6. Jej odmianą jest autonomia terytorialna, prowadząca do ograniczenia na danym obszarze zakresu władzy organów szczebla centralnego.

Celem autonomii terytorialnej jest zagwarantowanie poszanowania praw określonych wspólnot terytorialnych. Dotyczą one przede wszystkim zamieszkiwania i administrowania określonym obszarem. Uznanie prawa do posiadania autonomii terytorialnej może być wynikiem dwojakiego rodzaju akceptacji. Państwo, którego częścią jest dane terytorium, musi zaakceptować jego specjalny status. $Z$ drugiej strony istotnym jest również uznanie i potwierdzenie autonomii przez społeczność międzynarodową ${ }^{7}$.

4 H. Komarnicki, Globalizacja życia społecznego - mit czy rzeczywistość, w: Europa Środkowo-Wschodnia a globalizacja, pod red. T. Wallasa, Poznań 2000, s. 38.

5 M. Golka, Cywilizacja. Europa..., s. 149-150.

6 Leksykon politologii, pod red. A. Antoszewskiego, R. Herbuta, Wrocław 1996, s. 27.

7 Leksykon współczesnych międzynarodowych stosunków politycznych, pod red. C. Mojsiewicza, Wrocław 1996, s. 32. 
O ile zarówno integracja, jak i globalizacja prowadzą do otwarcia i liberalizacji to autonomia ma na celu głównie ochronę. Prowadzi więc do ustanowienia barier w ramach większego organizmu. Problemem pozostaje możliwość utrzymania dotychczasowych zasad autonomii w sytuacji, gdy państwo, w ramach którego ona istnieje, przystępuje do ugrupowania integracyjnego, a więc otwiera się na większą grupę państw. W sytuacji takiej, z punktu widzenia autonomii terytorialnej, może dojść do jej ograniczenia na jednej lub wielu płaszczyznach. W efekcie istnieje niebezpieczeństwo osłabienia któregoś z aspektów ochrony. Druga możliwość to zachowanie lub nawet wzmocnienie dotychczas obowiązujących zasad, poprzez uzyskanie zespołu derogacji, gwarancji i wyjątków. W pierwszym przypadku dla ochrony interesów danej grupy optymalnym rozwiązaniem jest pozostanie poza strukturą integracyjna, w drugim pełne wykorzystanie płynących z niej możliwości.

Niektóre europejskie obszary autonomiczne zostały postawione w sytuacji wyboru dotyczącego uczestnictwa w procesie integracji europejskiej. W przypadku Grenlandii, która wraz z Danią przystąpiła do Wspólnot, wprowadzenie autonomii w roku 1978 umożliwiło przeprowadzenie referendum na wyspie. W jego efekcie opuściła ona Wspólnoty w roku $1985^{8}$. Decyzja taka, podyktowana szeregiem czynników, miała przede wszystkim zagwarantować wyspie rozwój. Otrzymała ona status terytorium zamorskiego i dostęp do wspólnego rynku w zamian za udostępnienie Wspólnotom stref połowowych ${ }^{9}$. Podobnie Wyspy Owcze, cieszące się autonomią od roku 1948 zdecydowały się pozostać poza jednoczącą się Europą w roku $1973^{10}$. Zupełnie odmienną strategię zastosowały Wyspy Alandzkie, które w przynależności do Unii Europejskiej dostrzegły szansę na umocnienie swojego autonomicznego statusu oraz osiąnięcie szeregu korzyści politycznych i ekonomicznych.

Jeżeli odrodzenie lokalności jest jednym z efektów globalizacji, to ona właśnie umożliwia małym narodom oraz grupom etnicznym czy kulturowym manifestowanie swojej odrębności i wyjątkowości. O ile jednak możemy proces odrodzenia regionalnego traktować jako skutek globalizacji, o tyle w przypadku Wysp Alandzkich ma on korzenie dużo wcze-

8 This is Greenland '99. The Official Directory. Country, Products and Services, Copenhagen 1999, s. 24-25.

9 Greenland 1997. Statistical Yearbook, s. 17.

10 J. Derbyshire, I. Derbyshire, Encyclopedia of World Political Systems, New York 2000, vol. 2, s. 820. 
śniejsze. Obecnie istniejące warunki w postaci integracji europejskiej oraz globalizacji umożliwiają jedynie silniejsze akcentowanie dążeń i tendencji występujących już poprzednio.

Jednocześnie jednak fakt globalizacji skłania do postawienia pytania o zasady odrębności etnicznej oraz o możliwość utrzymania „własnej unikatowej odrębności, pozycji małych narodów i państw w ugrupowaniach regionalnych" ${ }^{\text {"11 }}$, tym bardziej, że do społecznych konsekwencji globalizacji oprócz ożywienia narodowego zaliczyć można m.in. migracje międzynarodowe $\mathrm{e}^{12}$. A to stanowi potencjalne zagrożenie dla obecnego charakteru obszarów autonomicznych i społeczności je zamieszkujących.

\section{Historyczne uwarunkowania autonomicznego statusu Wysp Alandzkich}

Wyspy Alandzkie stały się przedmiotem zainteresowania państw europejskich wraz z postanowieniami pokoju w Haminie w roku 1809, na mocy którego zostały one przekazane wraz z Finlandią Rosji. Ze względu na ich strategiczne położenie, po wojnie krymskiej Anglia i Francja zażądały demilitaryzacji wysp ${ }^{13}$. Problem ich przynależności pojawił się ponownie na arenie międzynarodowej w roku 1917, kiedy to Finlandia uzyskała niepodległość. Mieszkańcy opowiedzieli się wtedy za przyłączeniem archipelagu do Szwecji. Ostatecznie decyzję przesunięto z konferencji pokojowej na forum Ligi Narodów ${ }^{14}$, która zdecydowała o przyznaniu ich Finlandii ${ }^{15}$. Jednakże decyzja ta została obwarowana szeregiem - mających satysfakcjonować wszystkie strony sporu - warunków i potwierdzona porozumieniem pomiędzy Finlandią i Szwecją ${ }^{16}$. Stały się one jednocześnie podstawą, na której rozwinęła się autonomia Wysp.

11 S. Łodziński, Etniczność, obywatelstwo i wielokulturowość w procesach globalizacji, w: Kultury pozaeuropejskie i globalizacja. Zderzenia, pod red. J. Zdanowskiego, Warszawa 2000, s. 49-50.

12 Ibidem, s. 48.

13 R. Pullat, Stosunki polsko-fińskie w okresie międzywojennym, Warszawa 1998, s. 66 .

14 Ibidem, s. 66-67.

15 Minutes of the Fourteenth Meeting of the Council, June $24^{\text {th }}$, L"eague of Nations Official Journal", nr 697, September 1921.

${ }^{16}$ Minutes of the Seventeenth Meeting of the Council, June $27^{\text {th }}$, „League of Nations Official Journal”, nr 701, September 1921. 
Do podstawowych uregulowań należały gwarancje dla ludności zamieszkującej Alandy oraz ich demilitaryzacja i neutralizacja ${ }^{17}$. Te pierwsze stanowiły wyraz obrony przed dominacją fińską na gruncie kulturalnym, ekonomicznym i demograficznym. Ich celem było zachowanie „szwedzkiego charakteru". Miało to być osiąnięte poprzez edukację w języku szwedzkim, zachowanie własności ziemi w rękach mieszkańców, ograniczeniach w prawach wyborczych w stosunku do osób spoza Wysp. Dodatkowo ich zarządca powinien był cieszyć się akceptacją miejscowej społeczności. Wyrazem konieczności uwzględnienia faktu przynależności archipelagu do Państwa Fińskiego było traktowanie Finów, którzy spędzili pięć lat na wyspach jako ich mieszkańców, a nie imigrantów. Postanowienia te znalazły swoje odzwierciedlenie w uchwalonym w roku 1922 przez Finlandię statucie dla Alandów. Zawierał on dodatkowo finansowe gwarancje autonomii w postaci prawa do dysponowania częścią podatków na nich zebranych oraz możliwość wprowadzenia własnych, lokalnych danin publicznych ${ }^{18}$. Demilitaryzacja rozumiana jako zakaz fortyfikowania Wysp oraz neutralizacja potwierdzone międzynarodowym porozumieniem miały być gwarantem, iż nie staną się one źródłem zagrożenia z militarnego punktu widzenia dla sąsiadów. Jednocześnie była to jednak gwarancja dla miejscowej ludności.

Należy zwrócić uwagę na fakt, iż mieszkańcy Wysp, jak i same ich terytorium były przedmiotem sporu pomiędzy dwoma państwami i obiektem zainteresowania kolejnych kilku. Ich traktowanie miało charakter przedmiotowy, jednakże w wyniku osiągniętych porozumień dało solidne podstawy do ich ochrony i autonomizacji. Okazało się być również przyczynkiem do politycznej i gospodarczej emancypacji Alandów oraz ich upodmiotowienia. Mechanizmy mające chronić je przed Finlandią, umożliwić miały w przyszłości obronę przed negatywnymi aspektami procesów globalizacji i integracji.

\section{Zagrożenia dla Wysp Alandzkich będące rezultatem procesu globalizacji}

W okresie kształtowania się ładu po Traktacie Wersalskim oraz później, w warunkach zimnej wojny, obrona tożsamości oznaczała ochronę przed kulturą fińską. Zachowanie ,szwedzkiego charakteru” Wysp było

17 Patrz: The Resolution of the Council of the League of Nations on the Aaland (Aland) Islands, 24 June 1921.

18 T. Cieślak, Historia Finlandii, Wrocław 1983, s. 245. 
jednoznaczne z uniemożliwieniem dominacji fińskiej na gruncie kulturowym, ekonomicznym i militarnym. Oznaczało to jednego partnera, z którym należało negocjować warunki autonomii. Dodatkowo istnieli jeszcze inni aktorzy, którzy popierali lub gwarantowali odrębność Wysp. Była to przede wszystkim Szwecja, która stanęła w obronie mieszkańców Alandów. Ale także Liga Narodów oraz państwa gwarantujące demilitaryzację Wysp $^{19}$. W czasie procesów globalizacyjnych, zagrożenie dla Alandów płynie poprzez postępującą integrację. Unifikacja zasad stworzyła zagrożenie końca specjalnego statusu archipelagu. Procesy integracyjne zachodzące w Europie wymagały wzajemnego dostosowania i ujednolicenia rozwiązań. Dodatkowo w miejsce zagrożenia utraty tożsamości płynącego z jednego źródła pojawiło się ich wiele: potencjalnie były nimi wszystkie państwa członkowskie Unii. Jednocześnie zmniejszeniu lub nawet likwidacji uległa rola dotychczasowych sojuszników w obronie odrębności. Paradoksalnie to Finlandia stała się głównym rzecznikiem oraz narzędziem, za pomocą którego Alandy mogły uchronić się przed negatywnymi dla siebie skutkami integracji oraz ograniczyć wpływ globalizacji.

Globalizacja w dziedzinie gospodarki oznacza przede wszystkim liberalizację w produkcji i przepływie towarów, co w praktyce powoduje częstokroć konieczność specjalizacji. Dotyczy to również sfery usług. W przypadku Alandów trudno mówić o zagrożeniu, gdyż ze względu na wielkość i populację skazane są one na import prawie wszystkich potrzebnych towarów. Głównym celem władz alandzkich było więc limitowanie możliwości podejmowania działalności gospodarczej oraz osiedlania się i nabywania praw politycznych przez nierezydentów. Specjalizacja okazała się być czynnikiem mogącym przynieść znaczne korzyści w nowej sytuacji, specjalizacja rozumiana jako koncentracja na określonym wycinku sektora usług - handlu wolnocłowym.

Analizując zagrożenia dla Wysp Alandzkich nie sposób pomiąć różnorakiego wpływu globalizacji i integracji na pozycję archipelagu. Według Władysława Szamańskiego „Unia Europejska najdalej zaawansowała proces integracji ekonomicznej i politycznej, mimo to globalizacja nie była świadomym celem integracji. A więc integracja w istotny sposób służyła globalizacji, chociaż integracja regionalna tego nie tylko nie zakładała, ale nie spodziewała się zmian o takim zakresie. Jeżeli bowiem

19 Dania, Estonia, Francja, Islandia, Włochy, Łotwa, Polska, Wielka Brytania, Szwecja i Niemcy. 
integracja jest procesem świadomie podejmowanym i odgórnie narzucanym, to globalizacja jest procesem w dużym stopniu spontanicznym i oddolnym" 20 .

Integrację europejską, uosabianą przez Unię Europejską, można postrzegać instytucjonalnie, jako organizację, podczas gdy globalizacja jawi się jako pozainstytucjonalny proces. Członkostwo w tej pierwszej jest więc aktem wyboru. Decydując się na akcesję państwo zgadza się mniej lub bardziej świadomie na potencjalne niedogodności. Proces globalizacji nie pozwala natomiast na nieuczestniczenie w nim, jako że możliwość „wystąpienia” z globalnych powiązań gospodarczych i oddziaływań kulturowych jest bardzo ograniczona ${ }^{21}$.

Wzajemne relacje pomiędzy procesami globalizacji i integracji mogą - na przykładzie Alandów - uwydatnić tendencje nieco inne niż w przypadku państw. Uważa się, iż jedną z przesłanek tworzenia regionalnych bloków integracyjnych jest ochrona przed negatywnymi skutkami globalizacji. Występując samodzielnie wiele krajów mogłoby nie podołać dostatecznie skutecznie wyzwaniom współczesnego świata ${ }^{22}$. W przypadku Alandów to integracja przyniosła bezpośrednio zagrożenie, którego źródłem w przypadku innych krajów była globalizacja. Zagrożeniem tym jest marginalizacja i normalizacja, czyli standaryzacja zgodna z regułami europejskiej współpracy i handlu. Dla archipelagu oznaczałoby to przekształcenie w jeden $\mathrm{z}$ wielu, niczym niewyróżniających się regionów, będącym kolejnym potwierdzeniem reguły, a nie wyjątkiem ${ }^{23}$.

\section{Alandy a Unia Europejska}

Status Wysp Alandzkich był przedmiotem skomplikowanych negocjacji. Trudności powodowane były względami technicznymi i ustawodawczymi ${ }^{24}$.

20 W. Szymański, Globalizacja wyzwania i zagrożenia, Warszawa 2001, s. 42.

21 Globalization and Finland. A raport on World Growing Together, The Center for Finnish Business and Policy Studies (EVA), www.eva.fi/english/julkaisut/global/sisallys.htm.

22 W. Szymański, Globalizacja..., s. 42.

23 P. Joenniemi, Aland in the New Europe: A Case of post-Sovereign Political Life, w: Autonomy and Demilitarisation in International Law: the Aland Islands ian a Changing Europe, pod red. L. Hannikainen, F. Horn, The Hague-London-Boston 1997, s. 15.

${ }^{24}$ Negocjacje akcesyjne. Wnioski z doświadczeń Austrii, Finlandii, Norwegii i Szwecji, Natolin 1999, s. 41. 
Autonomiczny status Alandów był powodem, dla którego ich mieszkańcy mogli samodzielnie podjąć decyzję dotyczącą przystąpienia do Unii Europejskiej. Zgodnie z Aktem o Autonomii, traktaty międzynarodowe stojące $\mathrm{z}$ nim $\mathrm{w}$ sprzeczności oraz wchodzące w zakres kompetencji władz lokalnych muszą zyskać aprobatę miejscowego parlamentu.

Obecnie w Unii znajduje się około dwudziestu terytoriów o statusie autonomicznym. Istnieją dwa modele takiego stanu. Terytorium może pozostawać poza Wspólnota, ale niektóre zasady zawarte w aquis communitaire stosują się do niego. Druga możliwość to sytuacja, gdzie terytorium należy do Unii, lecz na określonych, specjalnych warunkach.

Mieszkańcy Wysp Alandzkich brali dwukrotnie udział w referendum. Specjalny, autonomiczny status wysp spowodował, iż głosowali oni po raz pierwszy jako obywatele Finlandii 16 października 1994 roku razem z resztą kraju. Wtedy to 52\% głosujących poparło członkostwo. Drugie referendum przeprowadzone zostało 20 listopada i dotyczyło przystąpienia Wysp Alandzkich do Unii Europejskiej na zasadach ustalonych w odrębnym porozumieniu ${ }^{25}$. Przy frekwencji wyborczej wynoszącej $49,1 \%$, poparcie dla uczestnictwa Alandów w Unii Europejskiej wyraziło 73,6\% wyborców, podczas gdy przeciwnego zdania było $26,4 \%{ }^{26}$. W przypadku odrzucenia przez mieszkańców propozycji przystapienia Alandy pozostałyby poza Wspólnotami ${ }^{27}$.

Wysokie poparcie dla integracji na Wyspach można łączyć z szeregiem gwarancji i przywilejów wynegocjowanym dla tego obszaru. Dotyczyły one m.in. ograniczenia prawa nabywania nieruchomości, osiedlania się, regulacji podatkowych i sprzedaży wolnocłowej ${ }^{28}$. Powodowało to niemożliwość wysuwania argumentów o obronie tożsamości oraz wykupie lub zalewie przez obcokrajowców. Jednocześnie istotne mogły okazać się względy kulturowe i historyczne. Drugie referendum na Alandach odbyło się po decyzji podjętej przez Szwecję. Z uwagi na fakt, iż mieszkańcy Wysp mają szwedzkie pochodzenie oraz posługują się językiem szwedzkim, ich decyzja oznaczała przystąpienie do organizacji, do której należeć miała także Szwecja.

25 F. Granell, The European Union's Enlargemt Negotiations with Austria, Finland, Norway and Sweden, „Journal of Common Market Studies”, vol. 33, no. 1, March 1995, s. 132.

26 Ålands statistik - och utredningsbyrå.

27 P. Luif, On the Road to Brussels. The Political Dimension of Austria's, Finland's and Sweden's Accession to the European Union, Wien 1995, s. 336.

28 Negocjacje akcesyjne. Wnioski..., s. 51. 
Pozytywny wynik referendum pozwolił rządowi fińskiemu na wydanie deklaracji o zastosowaniu Traktatu o Wspólnocie Europejskiej, Traktatu o Europejskiej Wspólnocie Węgla i Stali oraz Traktatu o Europejskiej Wspólnocie Energii Atomowej do terytorium Wysp Alandzkich ${ }^{29}$. Stało się tak na podstawie art. 28 Traktatu Akcesyjnego, który określał, iż jego postanowienia nie stosują się do Wysp Alandzkich, chyba, że rząd fiński zgłosi, iż tak nie jest.

Regulacje określające pozycję Wysp Alandzkich w Unii Europejskiej zostały określone w Traktacie Akcesyjnym ${ }^{30}$ : zarówno w samej jego treści, jak i w Protokole Dodatkowym Nr 2. Obydwa te dokumenty są częścią prawa pierwotnego Unii, przez co nie mogą być zmienione przez unijne regulacje. Wynika z tego, iż uzyskane przez Alandy przywileje są bardzo mocno osadzone w porządku prawnym Wspólnoty.

Zgodnie z postanowieniami Protokołu Nr 2 Alandy otrzymały derogacje w kilku obszarach problemowych. Po pierwsze, z uwzględnieniem niedyskryminacyjnego charakteru, osoby fizyczne nieposiadające regionalnego obywatelstwa, oraz osoby prawne nie mogły nabywać ani posiadać własności ziemskiej bez zgody odpowiednich władz alandzkich. Dotychczas takie same zasady dotyczyły obywateli fińskich nieposiadających prawa domicylu. Dodatkowo w podobny sposób ograniczono możliwość tychże osób do zakładania i prowadzenia działalności gospodarczej.

Rozwiązanie to stało w sprzeczności z obowiązującymi w Unii Europejskiej przepisami dotyczącymi podstawowych wolności zawartych w Programie Rynku Wewnętrznego. Art. 52-56 traktatu rzymskiego gwarantują prawo do podejmowania działalności gospodarczej przez osoby fizyczne i prawne na terytorium wszystkich państw członkowskich oraz nabywania i własności gruntu ${ }^{31}$. Było jednak wyrazem poszanowania

29 Declaration by the Government of Finland on the application of the EC Treaty, the ECSE Treaty and the Euratom Treaty to the Aland Islands.

30 Traktat pomiędzy Królestwem Belgii, Królestwem Danii, Republika Federalna Niemiec, Republika Helleńska, Królestwem Hiszpanii, Republika Francuska, Irlandia, Republika Włoska, Wielkim Księstwem Luksemburga, Królestwem Holandii, Zjednoczonym Królestwem Wielkiej Brytanii i Irlandii Pólnocnej (państwami Członkowskimi Unii Europejskiej) a Królestwem Norwegii, Republikq Austrii, Republika Finlandii, Królestwem Szwecji, o przystapieniu Królestwa Norwegii, Republiki Austrii, Republiki Finlandii, Królestwa Szwecji do Unii Europejskiej w: Dokumentacja Akcesyjna. Dokumenty dotyczqce przystapienia do Unii Europejskiej Austrii, Finlandii $i$ Szwecji, pod red J. Plaňavovej-Latanowicz, t. 3, Warszawa 1998.

31 Unia Europejska, praca zbiorowa, Warszawa 1997, s. 237. 
przez Unię rozwiązań obowiązujących dotychczas na terenie Wysp i ich ochrony.

Liberalizacja ograniczeń w zakupie ziemi jest jednym z efektów globalizacji i integracji. Podmioty gospodarcze uczestniczące w globalnym handlu i produkcji potrzebują swobody w kupnie ziemi pod inwestycje, jak również w innych celach. Głównym dylematem państw narodowych jest zatem znalezienie optymalnego rozwiązania pomiędzy umożliwieniem potencjalnym inwestorom lokowania swych pieniędzy a tradycyjnie rozumianą suwerennością.

W przypadku małych, autonomicznych terytoriów kwestia własności ziemi jest wyznacznikiem możliwości zachowania miejscowej specyfiki i ochrony kultury miejscowej społeczności. Masowy wykup ziemi mógłby w krótkim czasie doprowadzić do zmiany charakteru danego terytorium. Zmiana struktury własności może mieć znaczne konsekwencje dla niewielkiej liczebnie populacji. Nawet w przypadku nielicznych nierezydentów nabywających ziemię względne zmiany mogą być znaczne ${ }^{32}$.

Pod względem posiadanych praw, dotyczących nabywania ziemi i prowadzenia działalności gospodarczej na terytorium Alandów, istniały trzy grupy osób o zróżnicowanym charakterze. Pierwsza składała się z osób posiadających prawo domicylu. Druga to inni obywatele Finlandii. Ostatnia, trzecia grupa to wszyscy nie-Finowie.

W praktyce pierwszą grupę stanowili rdzenni, zakorzenieni w szwedzkiej kulturze i języku mieszkańcy. Stanowili oni niewielką liczebnie społeczność, łatwą do zdominowania demograficznie, a przez to kulturowo i ekonomicznie. Posiadała ona pełnię praw. Ochrona tej grupy stanowiła powód dla istniejących restrykcji i ograniczeń. Druga grupa posiadała nieograniczoną możliwość zamieszkiwania na wyspach, lecz dotyczyły ją ograniczenia w prawach politycznych i gospodarczych. Jednocześnie jednak grupa ta mogła otrzymać część lub pełnię praw poprzez uzyskanie miejscowego obywatelstwa. To z kolei wymagało stałego zamieszkania przez okres pięciu lat. W swych założeniach grupa pierwsza miała być chroniona głównie przed grupą drugą. Istota ograniczeń sprowadzała się do stworzenia możliwości uzyskania pełni praw dla tych jednostek, które zostaną inkorporowane przez lokalną społeczność - przestaną być obce.

32 Problem ten najlepiej ilustruje konflikt, który pojawił się pomiędzy społecznością Majorki a Niemcami, masowo wykupującymi grunty na wyspie. Brak zrozumienia ze strony nowych przybyszów dla tradycji prawa przejścia przez grunty prywatne doprowadził do poczucia zagrożenia miejscowej ludności i eskalacji konfliktu. 
Poprzez ich asymilację nie będą zagrożeniem, a staną się częścią społeczności zainteresowaną w utrzymaniu jej wyjątkowości.

Osoby przynależące do trzeciej grupy mogły osiedlić się na ogólnych zasadach osiedlania się w Finlandii, lecz uzyskanie przez nie pełni praw wymaga uzyskania prawa domicylu.

Dodatkowo kontrowersyjna pozostawała kwestia nieskrępowanego prawa do udziału w wyborach lokalnych: municypalnych oraz do lokalnego parlamentu - Lagtingetu. W przypadku pierwszych, przed akcesją mogli brać w nich udział mieszkańcy wysp z prawem domicylu oraz obywatele Finlandii, Szwecji, Danii, Norwegii i Islandii, którzy zamieszkiwali na Archipelagu przez trzy lata. Protokół Nr 2 nie zawierał jednak takiego wyjątku. Zgodnie z art. 8b(1) Traktatu o Utworzeniu Wspólnoty Europejskiej „Każdy obywatel Unii, zamieszkały na terenie państwa członkowskiego, którego nie jest obywatelem, posiada prawo do głosowania i kandydowania w wyborach samorządowych w państwie członkowskim, na terenie którego przebywa, na takich samych zasadach jak obywatele tego państwa". Z powodu specyficznych problemów istnieje jednak możliwość derogacji. Traktat Akcesyjny w punkcie F pozostawiał Komisji decyzję, czy takie specyficzne problemy istnieją w przypadku Alandów ${ }^{33}$. Ta wyraziła wątpliwość co do zasadności derogacji i zaleciła umożliwienie obywatelom fińskim, nie posiadającym prawa domicylu oraz obywatelom innych krajów członkowskich Unii, udział w wyborach. Prawo podjęcia ostatecznej decyzji pozostawiono jednak Radzie Unii Europejskiej ${ }^{34}$.

Specjalny status był cena, na jaką Unia Europejska musiała zgodzić się, aby Alandy zdecydowały się przystąpić do tej organizacji. Wyspy zostały również wyłączone z harmonizacji podatków obrotowych oraz akcyzy, co umożliwiło im utrzymanie statusu „tax-free”35. Alandy zostały

${ }^{33}$ K. Myntti, M. Scheinin, The Right of Domicile in the Aland Islands in the Light of Human Rights Treaties and the European Integration Process, w: Autonomy and Demilitarization in International Law: the Aland Islands in a Changing Europe, pod red. L. Hannikainen, F. Horn, The Hague-London-Boston 1997, s. 146.

${ }^{34}$ Ostatecznie w wyborach municypalnych mogą brać udział osoby z prawem domicylu lub mieszkające na wyspach przez trzy lata, a do parlamentu osoby z prawem domicylu i fińskim obywatelstwem. Zob.: Oficjalna strona Wysp Alandzkich, www.aland.ax; N. Fagerlund, The Special Status of the Aland Islands in the European Union, w: Autonomy and Demilitarization in International Law: the Aland Islands in a Changing Europe, pod red. L. Hannikainen, F. Horn, The Hague-London-Boston 1997, s. 211-212.

${ }^{35}$ P. Luif, On the Road to Brussels. The Political..., s. 336-337. 
wyłączone z implementacji terytorialnej postanowień dotyczących podatków pośrednich ${ }^{36}$, pozostając tzw. „terytorium trzecim”. Jako takie, znajduje się ono poza granicami celnymi Unii i Finlandii, co nie jest do końca korzystne dla miejscowych producentów. Chcąc poprawić ich sytuację, Finlandia uprościła formalności celne w stosunku do archipelagu.

Umożliwiające sprzedaż bezcłową terytorialne zwolnienie z opodatkowania, dotyczące w praktyce promów pływających z oraz na Wyspy, nie zostało ograniczone czasowo. Jedyną możliwością zmiany dotychczasowej sytuacji jest decyzja Komisji Europejskiej, gdy uzna ona, „[...] że prowizje nie są dłużej uzasadnione, zwłaszcza w ramach zdrowej konkurencji czy własnych zasobów. W takiej sytuacji Komisja przedstawi odpowiednie propozycje Radzie[...]"37. Rozwiązanie takie w połączeniu z utrudnieniami w nabywaniu własności ziemskiej i zakładaniu firm ma zapobiec przekształceniu Wysp w „raj podatkowy”, co było przedmiotem obaw ze strony państw członkowskich podczas negocjacji akcesyjnych.

Sklepy wolnocłowe przestały istnieć w Unii Europejskiej od 1 lipca 1999 roku. Decyzja ta, planowana początkowo na rok 1993 została przesunięta w czasie ze względu na opór lobby związanego z tego rodzaju handlem. Szacuje się, że owa przynosząca ogromne zyski przede wszystkim liniom lotniczym oraz promowym dziedzina gospodarki zatrudniała około 150 tysięcy pracowników ${ }^{38}$. W przypadku Alandów związana z niąjest większa część tamtejszej gospodarki. Po zmianach wewnątrz Unii Wyspy Alandzkie zachowały prawo do handlu wolnocłowego ${ }^{39}$. Sprzedaż bezcłowa jest nadal możliwa nie tylko na promach kursujących pomiędzy Szwecją i Finlandią, ale również pomiędzy Alandami i Finlandią.

Niewątpliwą korzyścią, jaką przyniosła Wyspom Alandzkim integracja europejska było wzmocnienie ich pozycji obszaru autonomicznego oraz neutralnego i zdemilitaryzowanego na forum międzynarodowym. W tym względzie Wyspy występowały w częściowej opozycji do stanowiska rządu fińskiego. Jednakże dzięki powstałej sieci wzajemnych powiązań zyskały one przychylność instytucji europejskich.

Traktat z 1940 roku dotyczący Wysp Alandzkich pomiędzy Związkiem Radzieckim a Finlandią potwierdzał wcześniejsze postanowienia dotyczące neutralizacji i demilitaryzacji. Dodatkowo zgodnie z postano-

36 F. Granell, The European Union's Enlargement..., s. 130.

37 Negocjacje akcesyjne. Wnioski..., s. 51.

38 A. Górski, Sezamie, zamknij się, „Polityka” 1999, nr 28.

39 A. Górski, Sezamie, zamknij się, „Polityka” 1999, nr 28. 
wieniami art. 5 Pokoju Paryskiego z 1947 r., pomiędzy „siłami sprzymierzonymi" a Finlandią Alandy zostały zdemilitaryzowane ${ }^{40}$. Pomimo zmiany sytuacji międzynarodowej po aksamitnej rewolucji Finlandia i Federacja Rosyjska potwierdziły w roku 1992 ważność traktatu z roku $1940^{41}$. Jednocześnie jednak w samej Finlandii pojawiły się głosy na rzecz przywrócenia normalności, czyli pełnej suwerenności nad Alandami pod względem militarnym. W praktyce oznaczałoby to możliwość ich remilitaryzacji i koniec neutralizacji. Nie były to jednak rozwiązania preferowane przez Alandy. Ostatecznie status terytorium neutralnego i zdemilitaryzowanego został potwierdzony pośrednio przez Preambułę Protokołu Nr 2, który stwierdza, iż wyspy posiadają specjalny status zgodny z prawem międzynarodowym $^{42}$.

Wiele czynników wskazywało więc na kontynuację specjalnego statusu wysp również po zakończeniu ,zimnej wojny”. Z drugiej strony jednak zaczęto podnosić fakt, iż wiele paradygmatów dotychczasowego porządku politycznego uległo zmianie, co implikowałoby również możliwość utraty wyjątkowego statusu Alandów. Uważa się, iż tracą one grunt dla bycia wyjątkowymi, ale jednocześnie potrafią nadrobić tę stratę w inny sposób. Znajdują się one pomiędzy dwoma konkurującymi ze sobą celami. Wykorzystują stare rozumowanie nastawione na pojęcie siły politycznej, ale jednocześnie potrafią odnaleźć się w nowej rzeczywistości, robiąc użytek z nowych pryncypiów. Uważa się, iż szczególność archipelagu „[...] przeważa i może nawet wzrosnąć podczas głębokich zmian mających miejsce pośród naczelnych zasad kierujących formowaniem nowego ładu polityczno-ekonomicznego"43.

Poza uzyskaniem określonych gwarancji mających zabezpieczyć autonomię i charakter Alandów oraz zagwarantować im korzyści ekonomiczne, Wyspy chciały również uzyskać wpływ, chociażby minimalny, na kształtowanie wspólnej polityki. Niestety wysuwane przez nie postulaty przekazania jednego z 16 fińskich mandatów do Parlamentu Europejskiego nie spotkały się z aprobatą władz w Helsinkach. Uzyskały natomiast

40 Peace Treaty of Paris 1947.

41 The Protocol on the Continuation of Bilateral Agreements between Russia and Finland in View of the Dissolution of the Soviet Union 1992.

42 A. Rosas, The Aland Islands as a Demilitarized and Neutralized Zone, w: Autonomy and Demilitarisation in International Law: the Aland Islands ian a Changing Europe, pod red. L. Hannikainen, F. Horn, The Hague-London-Boston 1997, s. 35.

43 P. Joenniemi, Aland in the..., s. 9-10. 
jednego przedstawiciela w Komitecie Regionów ${ }^{44}$. Zwiększeniu uległ również udział Wysp w kreowaniu polityki zagranicznej Finlandii. Rząd Alandów uzyskał prawo dostępu do informacji o pracach w instytucjach unijnych nad kwestiami, które mogą ich dotyczyć. Zagwarantowano mu również udział w pracach rządu fińskiego nad kwestiami europejskimi, których skutki obejmować będą archipelag. Może on również przygotowywać odpowiedzi Finlandii w omawianym zakresie.

\section{Podsumowanie}

Model autonomii wypracowany przez wyspy Alandzkie może dostarczyć wielu ciekawych rozwiązań dla innych obszarów. Autonomia terytorialna jako sposób na zapewnienie praw politycznych i gospodarczych mniejszości wymaga również sprostania wyzwaniom, jakie niesie ze sobą integracja europejska oraz globalizacja. Wydaje się, że z zadaniem tym poradziły sobie w sposób zadowalający Wyspy Alandzkie.

Po pierwsze potrafiły skutecznie przedstawić i promować własne interesy podczas negocjacji akcesyjnych. Po drugie utrzymały one (i dodatkowo wzmocniły poprzez włączenie do aquis communitaire) swój odrębny, autonomiczny status i gwarancje ochrony tożsamości, ograniczając prawo do nabywania ziemi i prowadzenia działalności gospodarczej przez osoby bez prawa domicylu. Po trzecie udało się im uzyskać specjalny status, wyłączający je z procesu harmonizacji podatków pośrednich, gwarantując w ten sposób znaczne korzyści gospodarcze. Po czwarte uzyskały potwierdzenie autonomii, demilitaryzacji i neutralizacji zarówno przez Finlandię, jak i Unię Europejska, utrzymując na nowych warunkach dawny status. Po piąte uzyskały przedstawicielstwo w Komitecie Regionów i określoną pozycję w sprawach europejskich w Finlandii.

Umiejętne wykorzystywanie istniejących rozwiązań wraz z uzyskaniem korzystnego zespołu derogacji i wyjątków umocniło pozycję Wysp w stosunku zarówno do Finlandii, jak i otoczenia międzynarodowego. Uległa wzmocnieniu ich ochrona ekonomiczna, kulturalna i polityczna. Wraz z uczestnictwem w organizacjach międzynarodowych, takich jak Rada Nordycka, Alandy pozostały aktywne i widoczne na arenie międzynarodowej.

44 F. Daftary, Insular Autonomy: a Framework for Conflict Settlement? A Comparative Study of Corsica and the Aland Islands, ECMI Working Paper \# 9, October 2000, s. 18 . 


\section{Summary}

The model of autonomy developed by the Aland Isles can provide a number of interesting solutions applicable in other territories. Territorial autonomy as a manner of ensuring the political and economic rights of the minority involves facing up to the challenges of European integration and globalization. It seems that the Aland Isles have successfully coped with this challenge. Firstly, they were able to present and promote their own interests during the accession negotiations in an efficient manner. Secondly, they maintained (and additionally strengthened by including it in the aquis communitaire) their separate, autonomous status and the guarantees of identity protection by virtue of limiting the rights of persons without domicile rights to purchase land and run business activity. Thirdly, they managed to obtain a special status excluding them from the process of indirect tax harmonization, thus ensuring considerable economic benefits. Fourthly, both Finland and the European Union confirmed their autonomy, demilitarization and neutrality allowing the Isles to retain their former status under the new circumstances. Fifthly, they obtained representation in the Committee of the Regions and a defined position on European matters in Finland. The skillful application of the existing solutions and the winning of an advantageous set of derogations and exceptions strengthened the position of the Isles both with respect to Finland and the international surroundings. The Isles' economic, cultural and political protection was augmented. Alongside their participation in international organizations, such as The Nordic Board, the Aland Isles have remained active and discernible on the international arena. 